CASEIN, a protein found in milk of several species, is divided into different chains from 19 to $25 \mathrm{kDa}$. Casein is also considered as a source of amino acids and generating peptides with biological activities such as opiate, immunostimulating, antibacterial, peptidase inhibitors, among others.

In this work, Sephadex G-10 chromatography followed by high-performance liquid chromatography isolation purified NZCase TT, an industrial culture media for tetanus toxin production. In the first step, four pools were isolated and tested in different assays: isolated smooth muscle assay (guinea pig ileum, rat uterus), phagocytosis in vitro of opsonized sheep red blood cells, and hydrogen peroxide $\left(\mathrm{H}_{2} \mathrm{O}_{2}\right)$ release from mouse peritoneal macrophages.

Pool III was the main active pool being able to potentiate bradykinin action in guinea pig ileum, stimulating phagocitic activity by resident macrophages and increasing $\mathrm{H}_{2} \mathrm{O}_{2}$ release from macrophages previously activated with bacille Calmette Guérin.

Using mass spectra the primary structure of the main peptide from pool III was obtained - INKKI, which corresponds to $\beta$-casein fragment $26-30$.

The immunostimulating action is probably related to a direct action in macrophage cells.

Key words: Mastoparan, Casein peptides, Inflammation, Macrophages, Peptide isolation

\section{Effects of 'casoparan', a peptide isolated from casein hydrolysates with mastoparan-like properties} \author{
São Paulo, Brazil

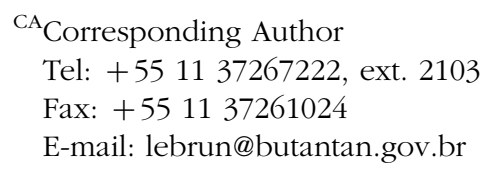

Ivo Lebrun ${ }^{1, C A}$, Valéria Cavallaro ${ }^{1}$, Luiz Juliano², Maria A. Juliano ${ }^{2}$ and Maria C. C. de Sousa e Silva ${ }^{3}$

${ }^{1}$ Biochemistry and Biophysics Laboratory, and ${ }^{3}$ Physiopathology Laboratory, Butantan Institute, São Paulo, Brazil and ${ }^{2}$ Biophysics Department, UNIFESP,

\section{Introduction}

The proteolytic digestion of large proteins generates small bioactive peptides. ${ }^{1}$ One of these proteins is casein and, besides its nutritional importance, revealed after tryptic and quimotryptic hydrolysis bioactive peptides able to regulate some important physiological pathways or acting in tissues, such as arterial blood pressure regulation, respiratory regulation, and in the immunological system among others. $^{2-4}$ These peptides can be generated after partial digestion and in some conditions could reach the blood stream, acting in different organs. This feature is particularly important in the newborn. ${ }^{5}$ Peptides with opiate and bradykinin (BK)-potentiating effects were isolated. ${ }^{3,6}$ Other important sources of bioactive peptides with high activity are found in venoms (snakes, spiders, scorpions) and in some insects such as wasp and ants. ${ }^{7}$ These peptides have neurotoxic and peripheral effects including cellular and immune responses. Recently, a new class of peptides called mastoparans was isolated from wasps and bee venoms, and displayed actions on macrophages, hemolytic activity and edema. ${ }^{8,9}$

Macrophages are phagocytic cells known to play an important role in the immune response and in the development of the inflammatory process and defense reactions, participating in defense reactions against foreign cells and particles. Macrophage activation results in functional changes that lead to bactericidal or tumoricidal activities and the release of various enzymes, arachidonic acid metabolites and reactive forms of oxygen, as well as the synthesis of cytokines. $^{10,11}$

Agents that show phagocytosis modulating activity and increase the functional capacity of the macrophage are of potential clinical significance. In this paper we describe the isolation and characterization of a new peptide derived from casein hydrolysates. We observed significant effects on rat arterial blood pressure and isolated guinea pig ileum, and in macrophages with an increase in phagocytosis and $\mathrm{H}_{2} \mathrm{O}_{2}$ liberation, showing that the isolated peptide from casein has a minimum structure that resembles mastoparan peptides obtained from wasp venoms.

\section{Methods: purification of bioactive peptides from casein hydrolysates (NZCase)}

\section{Molecular ultrafiltration}

Ten milliliters of a $10 \%$ solution $(\mathrm{w} / \mathrm{v})$ of NZCase in $0.02 \mathrm{M}, \mathrm{pH} 7.0$ of sodium phosphate, was first 
filtrated with an Ultrafree-15 (Millipore, Bedford, MA, USA) molecular weight cut-off membrane of $5 \mathrm{kDa}$ (this procedure was repeated six times). The filtrated material $(8 \mathrm{ml})$ corresponding to $375 \mathrm{mg}$ of the crude material was submitted to gel filtration chromatography in a Sephadex G-10 column (Amersham Biosciences, Uppsala, Sweden).

\section{Sephadex G-10 gel filtration chromatography}

The ultrafiltrated material $(8 \mathrm{ml})$ corresponding to $375 \mathrm{mg}$ of protein was applied to a Sephadex G-10 column $\left(4 \times 65 \mathrm{~cm}^{2}\right)$, previously equilibrated with sodium phosphate buffer solution (0.02 M, pH 7.0) and eluted with the same buffer with a $12 \mathrm{ml} / \mathrm{h}$ flow rate. Fractions of $3 \mathrm{ml}$ were collected by a LKBPharmacia Redifrac fraction collector and each fraction was read in $280 \mathrm{~nm}$ in a Micronal Model B382 spectrophotometer (Micronal, São Paulo, Brazil). Fractions corresponding to peaks were kept together in four pools that were lyophilized and stored at $-20^{\circ} \mathrm{C}$. The protein of each pool was determined by the Lowry ${ }^{12}$ method and compared with an albumin standard calibration curve.

\section{High-performance liquid chromatography purification}

After determination of the biological activity on isolated guinea pig ileum, pool III was submitted to high-performance liquid chromatography (HPLC) purification with an HP-1100 series liquid chromatograph coupled to an analytical reversed-phase $\mathrm{C}_{18}$ column $(4.6 \mathrm{~mm} \times 250 \mathrm{~mm})$ Beckmann $5 \mu$ ultrasphere ODS (Beckmann, San Ramon, CA, USA) using a linear gradient of acetonitrile in water-trifluoroacetic acid (0.1\%) from $0-45 \%$ in $60 \mathrm{~min}$ to $45-90 \%$ in $30 \mathrm{~min}$ with a $1 \mathrm{ml} / \mathrm{min}$ flow rate, monitored at $214 \mathrm{~nm}$. The main peaks were manually collected, lyophilized and stored at $-20^{\circ} \mathrm{C}$.

\section{Peptide sequence}

The HPLC-isolated active peak from pool III of the Sephadex G-10 chromatography was sequenced by Edman degradation in a Shimadzu sequencer apparatus model PSPQ-1 (Shimadzu, Kioto, Japan) and the sequence was confirmed by amino acid analysis following the method previously described by Heiriksson and Meredith, ${ }^{13}$ and also by mass spectra in a triple quadrupole Micromass mass spectrometer model Quatro II (Micromass, Milford, MA, USA) by analyzing the mass weight spectra of the generated peptides and amino acids.

\section{Peptide synthesis}

After primary sequence determination of the peptide, the synthetic peptide was obtained by liquid phase synthesis, and the identity of the effects obtained with the natural and synthetic peptide was checked as described previously by Juliano and Juliano. ${ }^{14}$

\section{Peritoneal cell preparation}

Animals were anesthetized with ether and killed through exsanguination by sectioning the cervical vessels. The peritoneal cavity was washed three times with cold phosphate-buffered saline (PBS), pH 7.4. After a gentle massage of the abdominal wall, the peritoneal fluid, containing resident macrophages, was collected. Elicited macrophages were obtained by peritoneal wash 4 days after intraperitoneal injection of thioglycollate broth (4\%). Activated cells were obtained by peritoneal washing 10 days after injection (intraperitoneally) of $2 \mathrm{mg}$ of heat-inactivated ONCO-BCG (bacille Calmette Guérin; Butantan Institute, São Paulo, Brazil). Cell viability was assessed by the trypan blue exclusion test ( $>95 \%)$. Total peritoneal cells were determined in a Neubauer's chamber, and the differential counts were performed in smears stained with Wright and May Giemsa modified stain methods. For all measurements, samples of individual animals were used.

\section{Phagocytic activity of peritoneal macrophages}

A suspension of sheep erythrocytes was diluted in PBS (0.5\%) and mixed (v/v) with rabbit antiserum against sheep erythrocyte; the mixture was then incubated for $30 \mathrm{~min}$ at $37^{\circ} \mathrm{C}$. The opsonized erythrocytes were centrifuged twice, at $184 \times \mathrm{g}$ for 10 min, with PBS and suspended with RPMI 1640 medium (0.5\%) for the phagocytosis assay. Briefly, the coverslips containing the adherent and spreading of peritoneal resident or elicited macrophages ${ }^{15}$ were incubated with $1 \mathrm{ml}$ of RPMI 1640 medium containing opsonized sheep erythrocytes, for $40 \mathrm{~min}$, at $37^{\circ} \mathrm{C}$, in an atmosphere containing $5 \% \mathrm{CO}_{2}$. The percentage of phagocytosis was determined by examination under a phase contrast microscope, by counting the percentage of cells that had phagocytosed more than five particles.

\section{Effect of the peptide on phagocytic activity: dose-response curve}

The effect of peptide over phagocytic activity of resident peritoneal macrophages was assessed in vitro. The cover slips containing adhered macrophages were incubated with RPMI 1640 medium (control) or RPMI 1640 containing the peptide (12.5, 25,50 and $100 \mu \mathrm{g} / \mathrm{ml}$ ) at $37^{\circ} \mathrm{C}$, in an atmosphere 
containing 5\% $\mathrm{CO}_{2}$. After $1 \mathrm{~h}$, the coverslips were washed with PBS and prepared for the phagocytosis assay.

\section{Hydrogen peroxide production}

Hydrogen peroxide production $\left(\mathrm{H}_{2} \mathrm{O}_{2}\right)$ was measured as described by Pick and Mizel ${ }^{16}$ and modified by Russo et al. ${ }^{17}$ Briefly, the peritoneal activated cells were adjusted to $1.5-2.5 \times 10^{6}$ cells $/ \mathrm{ml}$ and centrifuged for $10 \mathrm{~min}$ at $1000 \mathrm{rpm}$ and $5^{\circ} \mathrm{C}$. The sediment was resuspended in $1 \mathrm{ml}$ of phenol red solution, containing $140 \mathrm{mM} \mathrm{NaCl}, 10 \mathrm{mM}$ potassium phosphate buffer, pH 7.0, with $0.5 \mathrm{mM}$ dextrose, $0.28 \mathrm{mM}$ phenol red (PRS), and $8.5 \mathrm{U} / \mathrm{ml}$ of horseradish peroxidase for $\mathrm{H}_{2} \mathrm{O}_{2}$ detection. The final volume of $7.4 \mathrm{ml}$ was obtained with Hank's solution. One hundred microliters of the cell suspension were plated onto each well of 96-well flat-bottomed tissue culture plates (Corning, New York, USA) and $10 \mu \mathrm{l}$ of the peptide $(5.0$ or $10.0 \mu \mathrm{g})$ or saline was added and incubated in a humidified atmosphere at $37^{\circ} \mathrm{C}$ for $1 \mathrm{~h}$. Vertical row number 1 was left without cells and filled with $100 \mu \mathrm{l}$ per well of PRS. The second and third verticals rows were used for the establishment of $\mathrm{H}_{2} \mathrm{O}_{2}$ standard curves. These wells were covered with $100 \mu \mathrm{l}$ of PRS, added to $10 \mu \mathrm{l}$ of $\mathrm{H}_{2} \mathrm{O}_{2}$ solution, resulting in a final concentration of $\mathrm{H}_{2} \mathrm{O}_{2}$ ranging from 5 to $40 \mu \mathrm{M}$.

The subsequent rows contained wells covered with $100 \mu \mathrm{l}$ of PRS in the absence (basal $\mathrm{H}_{2} \mathrm{O}_{2}$ production) or the presence of phorbol myristate acetate (PMA) (20 ng). After $60 \mathrm{~min}$ incubation at $37^{\circ} \mathrm{C}$, the reaction was stopped by the addition of $10 \mu \mathrm{l}$ of $1 \mathrm{~N} \mathrm{NaOH}$ solution. $\mathrm{H}_{2} \mathrm{O}_{2}$-dependent phenol red oxidation was measured spectrophotometrically at $620 \mathrm{~nm}$, in a Labsystem Multiscan apparatus (Labsystem, Helsinki, Finland). The concentration of $\mathrm{H}_{2} \mathrm{O}_{2}$ was calculated from absorbance measurements, as described by Pick and Mizel $^{16}$ and expressed as nmoles of $\mathrm{H}_{2} \mathrm{O}_{2}$ per milliliter per $2.5 \times 10^{5}$ cells using the linear regression calibration curve for each assay.

\section{Isolated guinea pig ileum and isolated rat uterus assays}

The terminal piece of the isolated guinea pig ileum and the rat uterus (from animals injected $18 \mathrm{~h}$ previously with $1 \mathrm{mg} / \mathrm{kg}$ of diethylstilbestrol) were used. The organs were suspended in a $5 \mathrm{ml}$ chamber filled with Tyrode's solution (138 mM NaCl, $2.7 \mathrm{mM}$ $\mathrm{KCl}, 1.05 \mathrm{mM} \mathrm{MgCl}_{2}, 1.8 \mathrm{mM} \mathrm{CaCl}, 0.42 \mathrm{mM}$ $\mathrm{NaHPO}_{4}, 11.9 \mathrm{mM} \mathrm{NaHCO} 3$, and $5.55 \mathrm{mM}$ glucose) containing atropine sulphate and diphenydramine $(1 \mathrm{mg} / \mathrm{ml})$ at $35^{\circ} \mathrm{C}$ for the isolated guinea pig ileum, and Jalon solution $(154 \mathrm{mM} \mathrm{NaCl}, 5.63 \mathrm{mM} \mathrm{KCl}$, $0.54 \mathrm{mM} \mathrm{CaCl}, 5.95 \mathrm{mM} \mathrm{NaHCO}$ and $2.8 \mathrm{mM}$ glucose) maintained at $29^{\circ} \mathrm{C}$ for the uterus. The solutions were bubbled with air, and the muscle contractions were recorded on a polygraph coupled to an isotonic transducer. The substances tested were preincubated with the smooth muscle for $1 \mathrm{~min}$. The BK potentiating effect of 'in vitro' and 'in vivo' experiments were calculated as described previously by Lebrun et al. ${ }^{3}$ One potentiation unit represents a twofold increase of ileum or uterus contraction for a constant BK dose. The standard error for these values was less than $5 \%$.

\section{Statistical analysis}

Statistical analysis was performed using analysis of variation test and the Student $t$-test and the StudentNewmann-Keuls test by means of the Primer software for statistical analysis first version and the $p<0.05$ significance level was adopted.

\section{Results}

From a 10\% solution of $8 \mathrm{~g}$ of casein digest (NZCase) previously submitted to molecular ultrafiltration in a $5 \mathrm{kDa}$ Ultrafree membrane, resulting in a $2 \mathrm{~g}$ filtrate that was applied to a Sephadex G-10 gel filtration chromatography column $(4 \times 65 \mathrm{~cm})$ with a $12 \mathrm{ml} / \mathrm{h}$ flow rate, fractions of $3 \mathrm{ml}$ were collected and the absorption was determined at $280 \mathrm{~nm}$, resulting in four main peaks (pool I, pool II, pool III and pool IV) (Fig. 1). The four pools were tested and the active pool III was the submitted to HPLC chromatography (Fig. 2), resulting in an isolated peak that was sequenced.

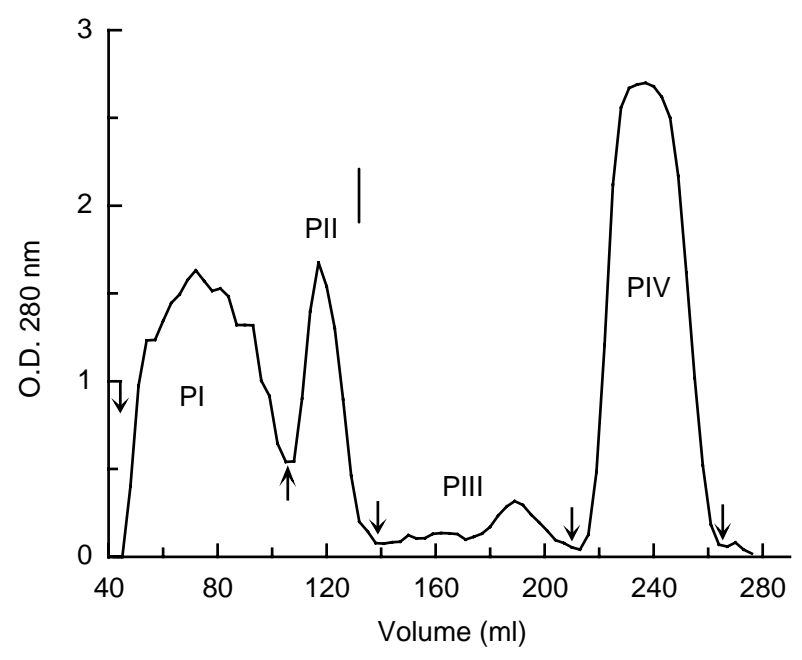

FIG. 1. Purification and isolation of casoparan peptide INKKI from casein hydrolysates (NZCASE). (A) Gel filtration chromatography purification of NZCase after ultrafiltration in a $5000 \mathrm{Da}$ membrane in a Sephadex G-10 column $\left(4 \times 65 \mathrm{~cm}^{2}\right)$ eluted with $0.02 \mathrm{M} \mathrm{Na}_{2} \mathrm{PO}_{4}, \mathrm{pH} 7.0$, solution, monitored at $280 \mathrm{~nm}$, flow rate of $12 \mathrm{ml} / \mathrm{h}$ and $3 \mathrm{ml}$ of each fraction. Pool III (PIII) showed actitivity and was purified by HPLC. 


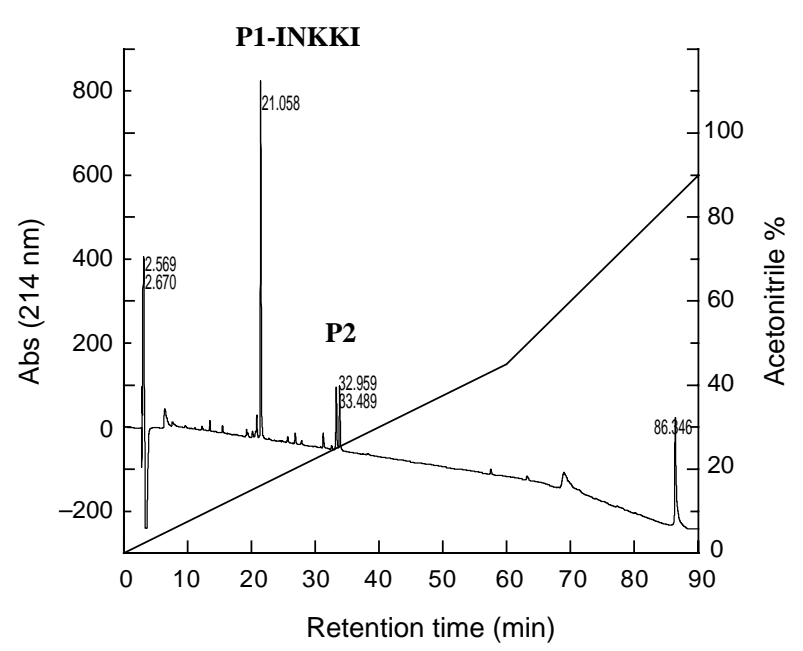

FIG. 2. HPLC chromatography of pool III obtained from Sephadex G-10 chromatography in a $\mathrm{C}_{18}$ analytical reversed-phase column eluted with a linear gradient of acetonitritrile $0-45 \%$ in $45 \mathrm{~min}$ and $45-90 \%$ acetonitrile in 45-70 $\mathrm{min}$ in TFA $0.1 \%$ (in water), flow rate of $1 \mathrm{ml} / \mathrm{min}$ monitored at $214 \mathrm{~nm}$.

\section{Mass spectra analysis}

After mass spectra of the HPLC-isolated peptide and analysis with the MassLynx and MaxEnt software, it was possible to obtain the sequence of the peptide INKKI that corresponds to the 26-30 fragment of the bovine beta-casein. The sequence was confirmed by sequencing in a PSPQ-1 Shimadzu sequencer by Edman degradation. The biological effects of the natural isolated peptide were confirmed using the synthetic peptide obtained by liquid phase synthesis, as described previously by Juliano and Juliano. ${ }^{14}$

\section{Biological assays}

Isolated guinea pig ileum assay was performed with the pools obtained from Sephadex G-10 gel filtration chromatography. The pools obtained from Sephadex G-10 gel filtration chromatography were tested on the isolated guinea pig ileum to observe the possible contractile effects or the BK-potentiating activity was determined as potentiating unity as described in Methods.

The same effect was observed using the isolated rat uterus and no intrinsic effect was observed with the two isolated smooth muscle preparations. Pool II revealed a dose-response relationship in potentiation of BK effects on isolated guinea pig ileum (Fig. 3), and from this pool the peptide INKKI was isolated as the main component by HPLC chromatography (Fig. 2).

Besides the potentiating effects on $\mathrm{BK}$, the action of the isolated peptide INKKI isolated after HPLC chromatography on macrophage functions was investigated. A dose-response relatioship was observed on macrophage erythrocyte phagocytosis with doses ranging from 10 to $100 \mu \mathrm{g} / \mathrm{ml}$, but over

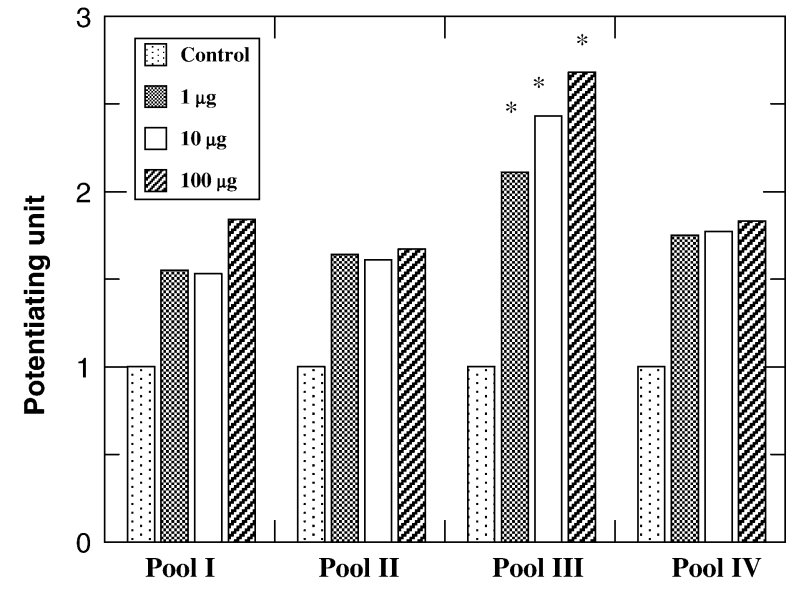

FIG. 3. BK-potentiating activity obtained with the isolated pools (I, II, III and IV) from a Sephadex G-10 column in the isolated guinea pig ileum. The potentiating-activity (PU) was calculated as described in Methods. Only pool III showed significant differences when compared with controls (Student $t$-test, ${ }^{*} p<0.05$ ).

$30 \mu \mathrm{g} / \mathrm{ml}$ a plateau is reached (Table 1 ). The peptide INKKI caused increase on phagocytosis by resident macrophage when compared with the control (saline). The concentration of the $25 \mu \mathrm{g} / \mathrm{ml}$ induced the higher increase (80\%) in the resident macrophage, suggesting that the peptide stimulates the phagocytic activities (Table 1).

No significant difference was observed when $25 \mu \mathrm{g}$ of the INKKI peptide was assessed in vitro on the phagocytic activity of the resident peritoneal macrophages; but the INKKI peptide showed a significant stimulatory effect on resident macrophages (Fig. 4).

The 5 or $10 \mu \mathrm{g}$ of INKKI caused an increase in the stimulated by PMA $(38 \%, 173 \%)$ and unstimulated $(30 \%, 38 \%)$ production of $\mathrm{H}_{2} \mathrm{O}_{2}$ of peritoneal activated macrophage (Fig. 5A,B).

\section{Discussion}

Phagocytosis is a process used by mononuclear phagocytes to ingest and clear large particles, including infectious agents, senescent cells and cellular debris. ${ }^{18}$ Particle internalization is started by the interaction of specific receptors on the surface of

Table 1. Dose-response activity of casoparan peptide (INKKI) on phagocytic activity of resident rat peritoneal macrophages

\begin{tabular}{lc}
\hline Dose $(\mu \mathrm{g} / \mathrm{ml})$ & Stimulation $(\%)$ \\
\hline 12.5 & 17 \\
25 & 80 \\
50 & 67 \\
100 & 47 \\
\hline
\end{tabular}

Results are expressed as percentage of controls. 


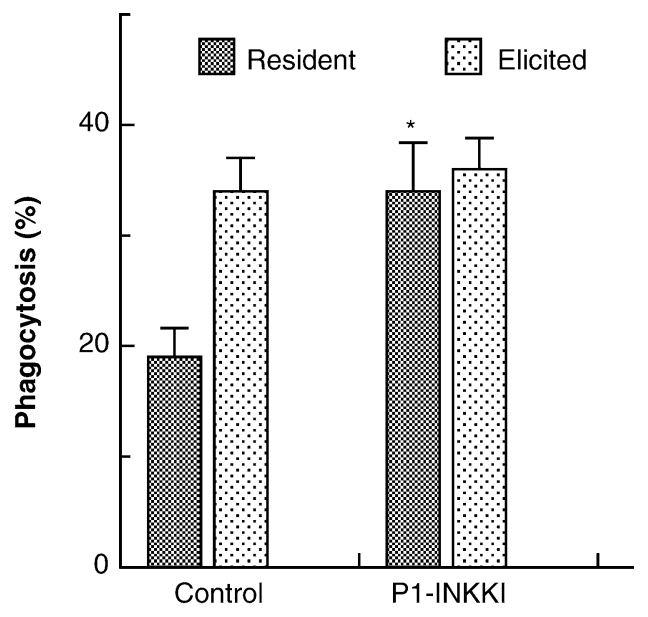

FIG. 4. Phagocytic activities of resident (dark shading) or elicited (light shading) peritoneal macrophages incubated with casoparan peptide INKKI $(25 \mu \mathrm{g} / \mathrm{ml})$ or saline (control group). The results are expressed as the mean \pm standard error of the mean for $8-10$ animals per group. ${ }^{*} p<0.01$, significantly different from the control group.
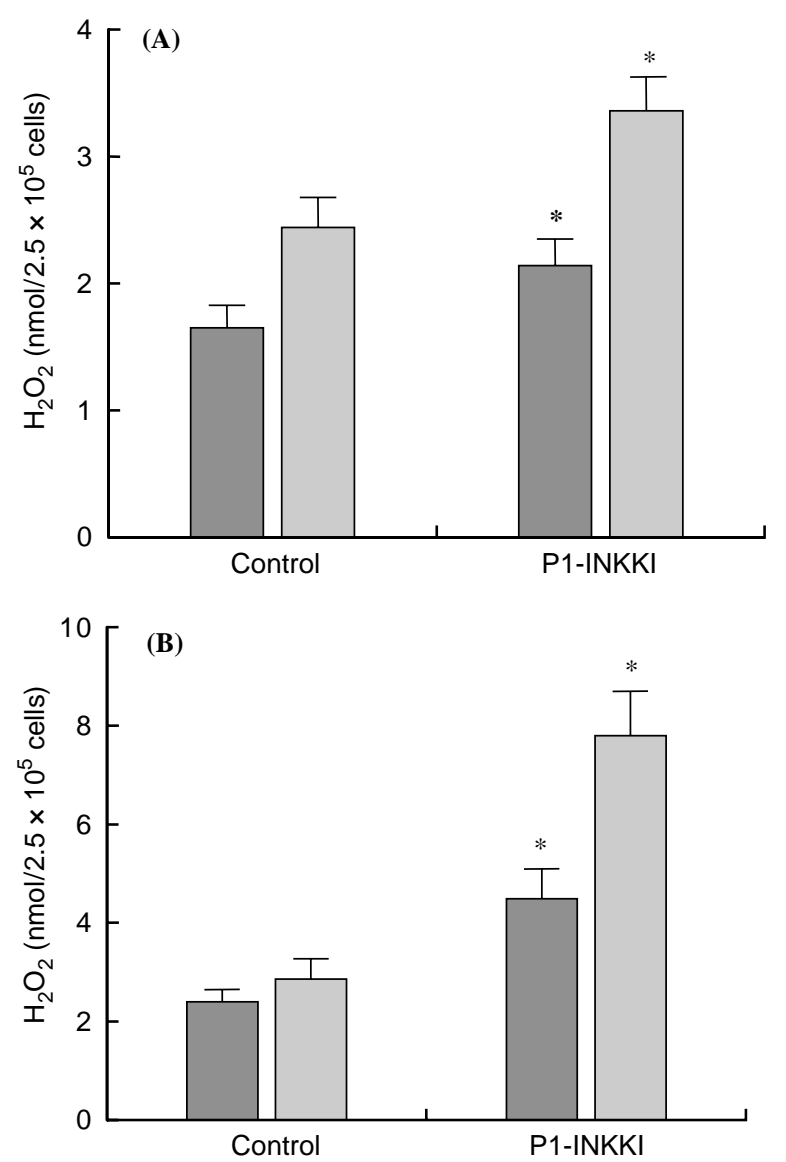

FIG. 5. Effects of the casoparan peptide INKKI, $5 \mu \mathrm{g}(\mathrm{A})$ and $10 \mu \mathrm{g}(\mathrm{B})$, on $\mathrm{H}_{2} \mathrm{O}_{2}$ production by peritoneal macrophages. The cells were obtained from the peritoneal cavity of mice injected 10 days before the experiments with BCG. $\mathrm{H}_{2} \mathrm{O}_{2}$ $\left(\mathrm{nmol} \mathrm{H} \mathrm{O}_{2} / 2.5 \times 10^{5}\right.$ cells $\left./ \mathrm{ml}\right)$ was determined in the absence (dark shading) or in the presence of PMA (light shading). The results are expressed as the mean + standard error of the mean for 8-10 animals per group. ${ }^{*} p<0.05$, significantly different in comparison between $\mathrm{H}_{2} \mathrm{O}_{2}$ production in the presence of PMA and in the absence of PMA. the phagocyte with binding on the surface of the particle. $^{19,20}$

Several studies have demonstrated the effects of peptides on the phagocytic activities of macrophages. ${ }^{5,21,22}$

Data presented herein showed that the peptide INKKI from HPLC isolation of pool III stimulates phagocytic activities of resident peritoneal macrophages in vitro mediated by the Fc receptor. Resident macrophages occur in specific sites in normal and non-inflamed tissues. Elicited macrophages are cells attracted to a given site because of a particle stimulus, independent of the developmental stage or functional state of the cells, and activated macrophages are cells with increased or new functional activities induced by a given stimulus. ${ }^{23}$

The results showed that the stimulant effects of the peptide depend on the cell activation stage since they are only observed on resident macrophages, which are quiescent cells. These cells are responsive to inflammatory or immunological signals. The increase of the phagocytosis observed in the resident cells was similar to the effects observed on elicited macrophages, suggesting that the peptide could act as a macrophage stimulation inducer. This stimulatory effect was dose dependent and 80\% stimulation was observed in the presence of the casoparan peptide INKKI $25 \mu \mathrm{g} / \mathrm{ml}$, while high doses induced a minor response, suggesting a possible saturation of the phenomena. Similar results were obtained when the synthetic peptides were used to assay the phagocytic activities.

The phagocytosis process stimulates the respiratory burst. ${ }^{24}$ The generation of reactive oxygen intermediates such as superoxide and $\mathrm{H}_{2} \mathrm{O}_{2}$ is a practical measuring system for the respiratory burst; ${ }^{25}$ and the reactive oxygen intermediates take part in the microbicidal mechanism used by macrophages and neutrophils. ${ }^{20}$ The peptide INKKI stimulated the production of hydrogen peroxide only in macrophages activated by BCG; this effect was observed in the presence or absence of PMA. However, the presence of PMA increases this production. Among the soluble stimuli, only PMA induces a marked respiratory burst with an abundant release of $\mathrm{H}_{2} \mathrm{O}_{2} \cdot{ }^{25}$ The results showed that the peptide as well as the PMA induce the respiratory burst. The PMA stimulates the oxidative burst, bypassing the need for receptor-ligand coupling stimulating a $\mathrm{Ca}^{2+}$ dependent protein kinase C. ${ }^{26,27}$ Therefore, the mechanism of the peptide actions remains unknown. Previous publications report that some peptide fragments of casein show immunostimulating or immunomodulator effects. ${ }^{28-30} \mathrm{~A}$ hexapeptide corresponding to the 54-59 fragment of human $\beta$-casein (VEPIPY) showed a stronger immunostimulating effect and conferred resistence in experimental infections with Klebsiella pneumoniae. ${ }^{31}$ Moreover, 
peptides isolated from wasp, bee and ant venoms, called Mastoparans, exhibit inflammatory properties, releasing histamine, provoking edema and cell migration to the inflammatory site. These peptides are approximately $1400 \mathrm{Da}$ and have a structure rich in Ile, Asn and Lys. ${ }^{32}$ The isolated pentapeptide INKKI showed the same motif present in the mastoparans less the neutral amino acids (Ala, Gli and Leu). The biological effects include an increase of phagocytosis and $\mathrm{H}_{2} \mathrm{O}_{2}$ production. These effects happen even in the presence of PMA, suggesting a specific pathway for the peptide action. The peptide INKKI also induced histamine release in rat arterial blood pressure and isolated guinea pig ileum, since the effect is blocked by diphenydramine (data not shown).

The effects displayed by casoparan peptide suggest that the generation of small peptides from large proteins with physiological functions is particularly important. In this particular feature, the peptide isolated from casein could lead to modulatory effects over inflammatory cells such as macrophages, increasing phagocytosis and $\mathrm{H}_{2} \mathrm{O}_{2}$ liberation without the development of inflammation. This aspect considering the physiological generation in the newborn could be an adaptive stimulus to the immature immunological system that is on development.

ACKNOWLEDGEMENTS. The authors are indebted to Valdeli Braga and Patricia Helena Camargo Sabença do Couto for technical assistance. Financial support was from FAPESP, CNPq and Fundação Butantan.

\section{References}

1. Schlimme E, Meisel H. Bioactive peptides derived from milk proteins. Structural, physiological and a analytical aspects. Nabrung 1995; 39: 120.

2. Migliore-Samour D, Jollès P. Casein, a prohormone with an immunomodulating role for the newborn? Experientia 1988; 44: 188-193.

3. Lebrun I, Lebrun FLAS, Henriques OB, Carmona AK, Juliano L, Camargo $\mathrm{ACM}$. Isolation and characterization of a new bradykinin potentiating octapeptide from $\gamma$-casein. Can J Physiol Pharmacol 1995; 73: 85-91.

4. Meisel H. Biochemical properties of regulatory peptides derived from milk proteins. Biopolymers 1997; 43: 119-128.

5. Fiat A-M, Migliore-Samour D, Jollès P, Drouet L, Sollier C, Caen J. Biologically active peptides from milk proteins with emphasis on two examples concerning antithrombotic and immunomodulating activities. J Dairy Science 1993; 76: 301-310.

6. Yamamoto N. Antihypertensive peptides derived from food proteins Biopolymers 1997; 43: 129-134.

7. Argiolas A, Pisano JJ. Isolation and characterization of two new peptides, mastoparan $\mathrm{C}$ and crabolin, from the venom of the European hornet, Vespa crabo. J Biol Chem 1984; 259: 10106-10111.

8. Ho CL, Lin YL, Chen WC, Hwang LL, Yu HM, Wang KT. Structural requirements for the edema-inducing and haemolytic activities of mastoparan B isolated from the hornet (Vespa basalis) venom. Toxicon 1996; 34: $1027-1035$.
9. Konno K, Hisada M, Naoki H, et al. Structure and biological activities of eumenine mastoparan-AF (EMP-AF), a new mast cell degranulating peptide in the venom of the solitary wasp (Anterhychium flavomarginatum micado). Toxicon 2000; 38: 1505-1515.

10. Adams DO, Hamilton TA. The cell biology of macrophage activation. Ann Rev Immunol 1984; 2: 283-318.

11. Bogdan C, Röllinghoff M, Diefenbach A. Reactive oxygen and reactive nitrogen intermediates in innate and specific immunity. Curr Opin Immunol 2000; 12: 64-76.

12. Lowry $\mathrm{OH}$, Rosebrough NJ, Farr AL, Randall RJ. Protein measurement with the Folin phenol reagent. J Biol Chem 1951; 193: 265-275.

13. Heinrikson RL, Meredith SC. Amino acid analysis by reverse highperformance liquid chromatography: precolumn derivatization with phenylisothiocyanate. Anal Biochem 1984; 436: 65-74.

14. Juliano MA, Juliano L. Synthesis and kinetic parameters of hydrolysis by trypsin of some acyl-arginyl-p-nitroanilides and peptides containing arginyl-p-nitroanilide. Braz J Med Biol Res 1985; 18: 435-445.

15. Rabinovitch M, De Stefano MJ. Macrophage spreading in vitro. Exp Cell Res 1973; 77: 323-324.

16. Pick E, Mizel D. Rapid microassays for the measurement of superoxide and hydrogen peroxide production by macrophages in culture using an automatic enzyme immunoassay reader. J Immunol Methods 1981; 46: $211-226$.

17. Russo M, Teixeira HC, Marcondes MC, Barbuto JA. Superoxideindependent hydrogen peroxide release by activated macrophages. Braz J Med Biol Res 1989; 22: 211-226.

18. Allen LA, Aderem A. Mechanisms of phagocytosis [Review]. Curr Opin Immunol 1996; 8: 36-40.

19. Aderem A, Underhill DM. Mechanisms of phagocytosis in macrophages. Annu Ver Immunol 1999; 17: 593-623.

20. Bogdan C. Macrophages. In: Encyclopedia of Life Sciences, New York: Nature Publishing, 2001: 1-9.

21. Berthou J, Migliore-Samour D, Lifchitz A, Delettré J, Floc'h F, Jollès P. Immunostimulating properties and three-dimensional structure of two tripeptide from human and cow caseins. FEBS Lett 1987; 218: 55-58.

22. Gattegno L, Migliore-Samour D, Saffar L, Jollès P. Enhacement of phagocytic activity of human monocytic-macrophagic cells by immunostimulating peptides from human casein. Immunol Lett 1988; 18: $27-$ 32.

23. Van Furth R. Origin and turnover of monocytes and macrophages. Curr Top Pathol 1989; 79: 125-150.

24. Johnston RB. Enhancement of phagocytosis-associated oxidase metabolism as a manisfestation of macrophage activation. Lymphokines 1981; 3: $33-56$.

25. Bagglioni M. Phagocytose activation and its modulation by drugs. In: Bonta IL, Bray M A, Parnham MJ, eds. Handbook of Inflammation, Vol 5: The Pharmacology of Inflammation, Amsterdam: Elsevier Science Publishers, 1985.

26. Castagna M, Takai Y, Kaibuchi K, Sano K, Kikkawa U, Nishizuka Y, Direct activation of calcium-activated, phospholipid-dependent protein kinase by tumor-promoting phorbol esters. J Biol Chem 1982; 257: $7847-7851$.

27. Niedel JE, Kuhn LJ, Vanderbark GR. Phorbol diester receptor copurifies with protein kinase C. Proc Natl Acad Sci USA 1983; 80: 36-40.

28. Jollès P, Parker F, Floc'h F, Migliore-Samour D, Alliel P, Zerial A, Werner $\mathrm{GH}$. Immunostimulating substances from human casein. J Immunopharm 1981-1982; 3: 363-369.

29. Kayser H, Meisel H. Stimulation of human peripheral blood lymphocytes by bioactive peptides derived from bovine milk proteins. FEBS Lett 1996; 383: $18-20$

30. Wong CW, Seow HF, Liu AH, Husband AL, Smithers GW, Watson DL. Modulation of immune response by bovine $\beta$-casein. Immun Cell Biol 1996; 74: 323-329.

31. Parker F, Migliore-Samour D, Floc'h F, et al. Immunostimulating hexapeptide from human casein: amino acid sequence, synthesis and biological properties. Eur J Biochem 1984; 145: 677-682.

32. Nakajima T. Pharmacological biochemistry of vespid venoms. In: Piek T, ed. Venoms of the bymenoptera. Biochemical, Pharmacological and Behavioural Aspects, New York: Academic Press, 1986: 309-327.

\section{Received 10 May 2004}

Accepted 21 June 2004 


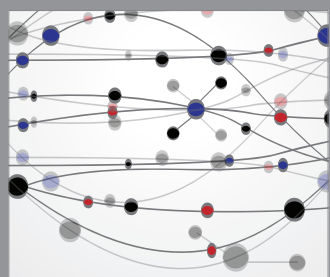

The Scientific World Journal
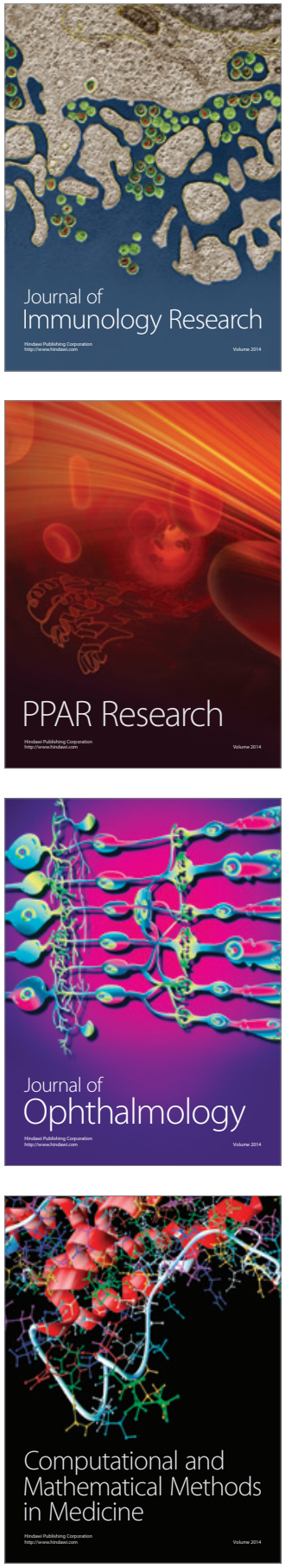

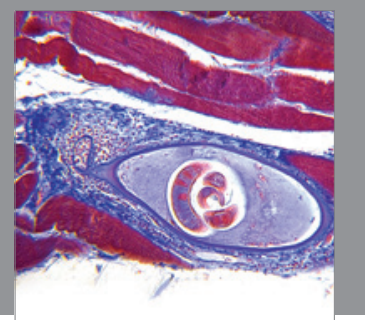

Gastroenterology

Research and Practice
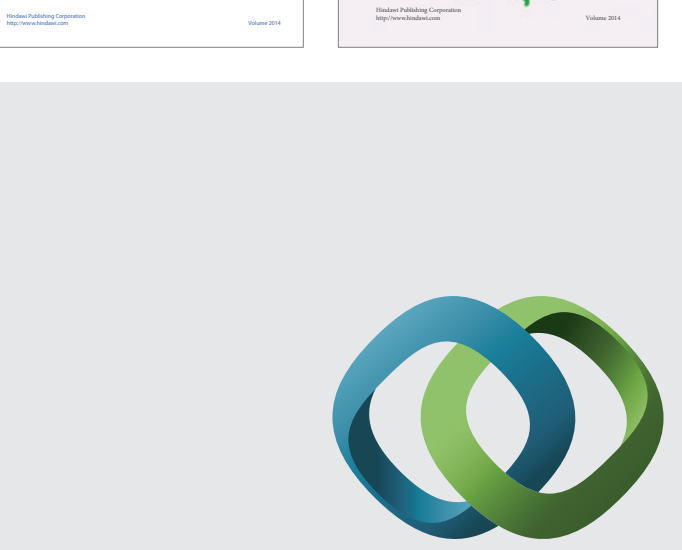

\section{Hindawi}

Submit your manuscripts at

http://www.hindawi.com
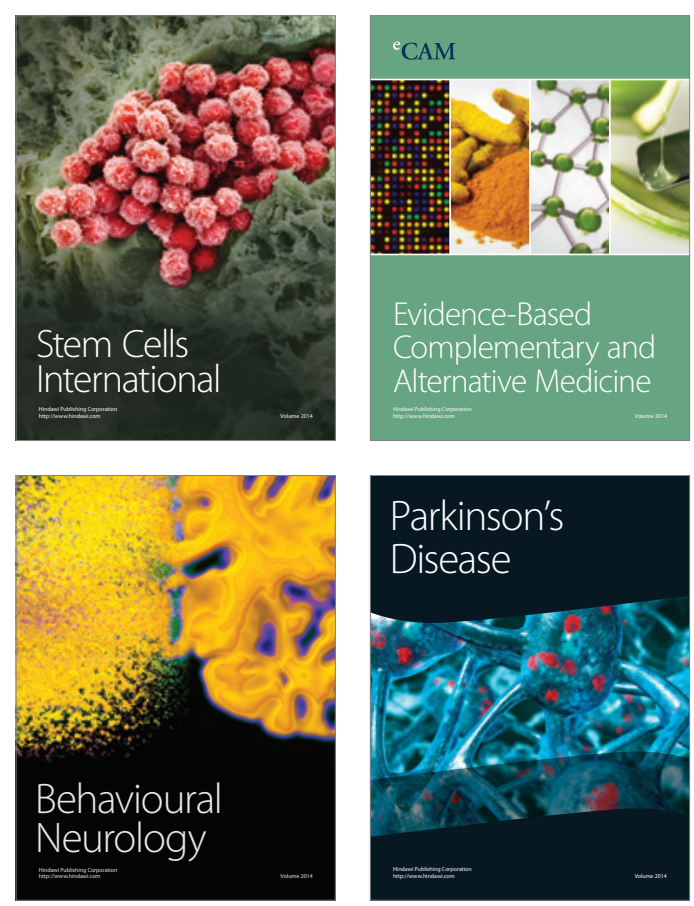

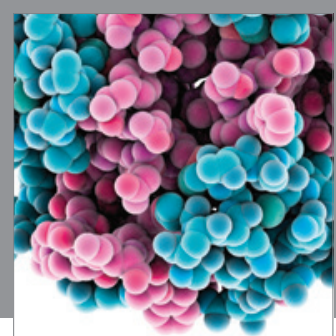

Journal of
Diabetes Research

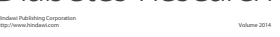

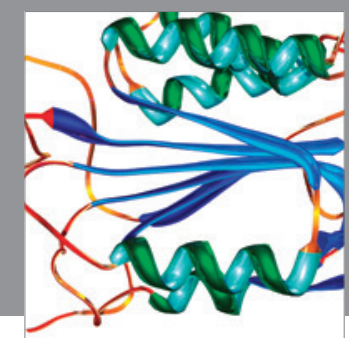

Disease Markers
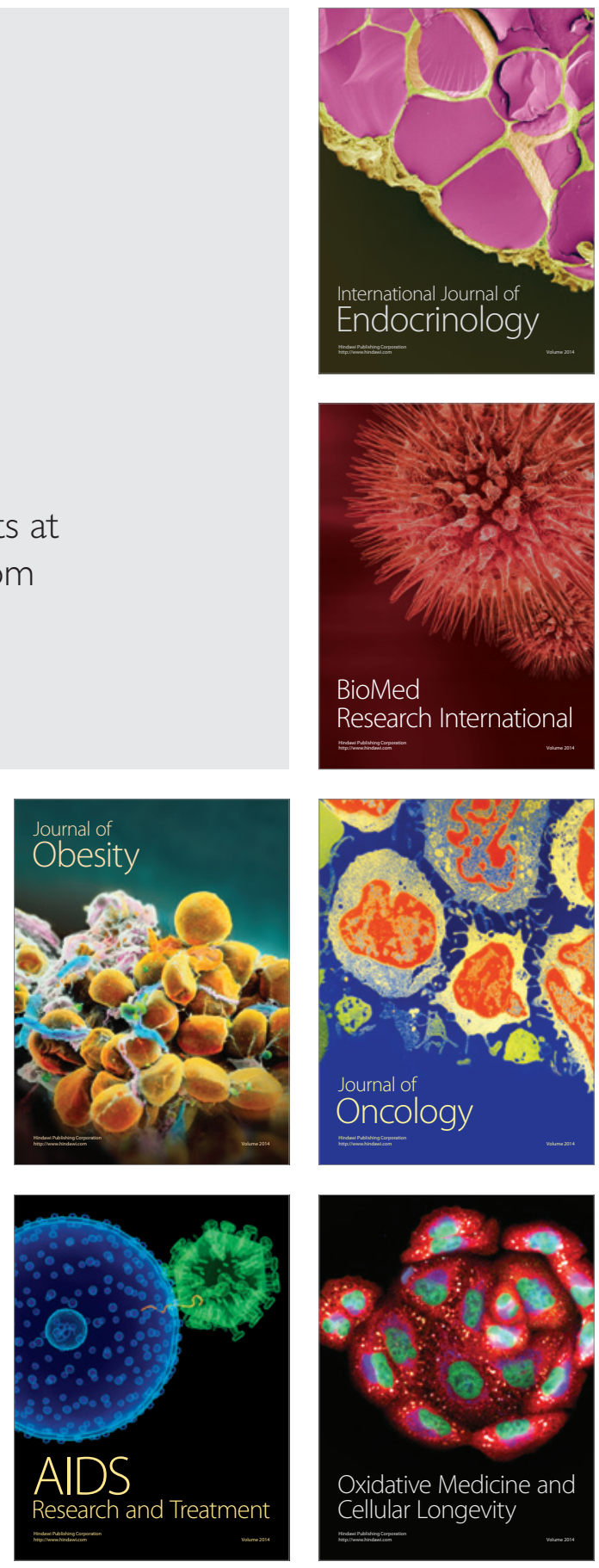